\title{
"STILL, I CAN HARDLY BELIEVE IT": REACTIONS, RESOURCES, AND RELIGION IN CONVERSATIONS ABOUT SEXUAL ABUSE OF CHILDREN AMONG LAESTADIANS IN FINLAND
}

\author{
Ulrika Wolf-Knuts \\ Emeritus Professor, Abo Akademi University \\ Turku, Finland \\ uwolf@abo.fi
}

\begin{abstract}
There are innumerable nuances in people's behaviour when they become frustrated. In this article I analyse interviews about a specific case when, in a relatively small Lutheran community, it turned out that a highly respected person, a leader and preacher, was a paedophile. The reluctant accepter, the disappointed accepter, and the explaining accepter are three types of narrators. What were their reactions, what resources did they apply in our conversation? Partly, religion played the role of an obstacle for further belief, but partly it was also a support for the members of the community.
\end{abstract}

Keywords: belief-disbelief, coping, Finland, Laestadianism, paedophilia, resources

\section{INTRODUCTION}

There are several ways of handling a critical situation. Some people deal with it by shrugging their shoulders. In some it even awakens a serious feeling of deceit, which must be processed. Others surrender to their feelings and give up. Sometimes frustration and disappointment lead to aggressiveness and/or a fighting spirit. In this article I analyse a specific case when, in a relatively small Lutheran community, it turned out that a highly respected person was a paedophile. I interviewed three members of the community about their reactions when they heard about the case. What resources did they apply in order to get a grip of the situation? Did their religion influence their reactions? ${ }^{1}$

The events of interest to me happened in a Laestadian revivalist group, a so-called association of peace, holding some 1,200 members ${ }^{2}$ and belonging 
to the Lutheran congregation in Jakobstad, western Finland. One of the most influential leaders, preachers, and Sunday school teachers turned out to have been a paedophile. He abused his own grandchildren, a couple of small boys. In fact, the molestations ended a little over twenty years ago, in the 1980s, but only in 2009 they became publicly known, when one of the abused children, now an adult man, spoke to the press (Lampa 2009). According to him, it turned out that his own grandfather used to sexually harass him and other small boys in his house. The news caused a shock to many of the members of the association of peace. At the time when the press published their articles, the grandfatherpreacher had passed away and also the period for prosecution had expired.

In 2012, I had the opportunity to interview a number of members in the Jakobstad association of peace. None of the interviewees had been a victim of the paedophile but all of them had lived near the victims and some of their relatives were married into his house. When I asked some members how they had reacted when they first learned that their leading preacher and their beloved teacher at Sunday school was sexually interested in small boys, they stated that they could not believe it. One of them was reluctant to believe what she heard, another one was deeply disappointed and almost disillusioned, and the third one found plenty of explanations for what had happened. I discuss what resources they made use of when they told me how they reacted to the paedophile's acts. In this case, their belief in a revivalist association might be a support for the members, but it might also play the role of an obstacle to further belief. ${ }^{3}$

Kenneth I. Pargament's (1997) research about coping highly inspired me to concentrate my analysis around the interviewees' reactions towards the narratives about this case of paedophilia in a small Laestadian community in Finland. According to him, we cope or find a way to reduce tension in a problematic situation many times a day. People choose between several possible options, all of which aim at significance for the coping person. Consequently, the components of the coping process are not generally fixed. In a situation of distress, people must choose among several options and pick out the one that is significant so that they can accept their choice and acknowledge it as the best one in the specific situation. Pargament states that people create orienting systems in accordance with which they conduct their coping process. An orienting system is a general worldview consisting of customs, values, relationships, beliefs, and personal characteristics. People pick the factors in their process of coping according to their personalities, their former experiences, their orientation to life, their resources, both material and mental, and their cultural context. Consequently, coping is a cultural process. However, it is not necessarily logical or sensible, and the chosen factors or the outcomes are not always positive - from an outside perspective. People's capacity to tolerate disappointment and crises is very different. 


\section{THE ASSOCIATION OF PEACE AND ITS RELIGIOUS AFFILIATION}

The Swedish clergyman Lars Levi Laestadius (1800-1861) introduced a Christian revivalist movement around the middle of the nineteenth century. $\mathrm{He}$ worked in northern Sweden, mainly among the Sámi people (Talonen 2014: 20-34; Raittila 1969: 99-101; Suolinna \& Sinikara 1986: 15). The movement spread all around the Arctic area in Europe and in the USA. Today it is international but it is most significant in Finland. There are seven different fractions of the Laestadian movement holding more than 1,000 members, and groups consisting of a smaller number of members are numerous (Talonen 2014: 19). The movement is faithful to the Bible. A strong personal recognition of sin, emotionally charged confessions and forgiveness are its characteristics (cf. Brännström 1962). The subdivision mostly represented in Finland (around 90,000 members), to which the Jakobstad association of peace belongs, is called Old Laestadianism (gammallaestadianismen; cf. Snellman 2011: 49.) This association of peace is part of a specific subgroup called Rauhan Sana (The Word of Peace), and holds some 10,000 members (Talonen 2016). ${ }^{4}$

\section{THE INTERVIEWEES AND RESEARCH ETHICS}

Astrid is a local politician and housewife, a lady around eighty years old, whereas Per is an entrepreneur in his fifties and Tim, also an entrepreneur, is some ten years younger. Each interview lasted about one hour. There was no hurry and, which is quite common, many good pieces of information emerged after the interview. I wrote them down as soon as possible. Each of the interviewees is a parent so they can imagine what it is like to have children that have been abused by an adult.

The interviews dealt with paedophilia. The interviewees told me about a grandfather who was a paedophile. Certainly, one might wish details about what happened. However, in this study I am not interested in what "really" happened. In this context sexual abuse does not need any detailed definition, and the interviewees also expected me to understand what they meant without any further descriptions. I was not able to interview the preacher, for he had passed away many years ago. Neither did I contact any of the victims, for their narratives were not in my focus. My main interest lay in the reactions among those who were not directly involved as victims or family members, but who were affected as a third party. Gossip, rumours or other kinds of narratives functioned as their sources. My interviews are my research material, 
and therefore I focus on them. There is no need or reason to doubt my interviewees' narratives about their experiences. I do not want to construct a series of "real" events that can only be conjectures, for the interviews do not contain any detailed information of what happened. Instead, I want to concentrate my investigation on my interviewees' reactions to the stories. A special emphasis lies on the reflections that people had when they thought of and told me about what they had heard. I concentrate my study on the information that, to the interviewees, was so important that they found it worthwhile to formulate it orally and communicate it to me. ${ }^{5}$

During the three years that passed between the disclosure and the interviews, the informants had certainly discussed the case both within and outside the community. In the interview they remembered and re-lived the situations from the past. This means that they told me a version of their experiences that was already a result of a process of selection between many alternative options. In the interviews, as we shall see, they had already reached some kind of acceptance of their situation, and some perhaps even felt equilibrium.

Ethical matters are certainly very important in a sensitive case such as paedophilia. Although the informants did allow me to present their recordings with their personal names, I decided to hide them as best I could. Still, I suspect that the interviewees would probably be recognised in their surroundings. In order to avoid problems with these issues, I let the interviewees read the transliterated interviews. None of them wanted to change anything in the texts.

I have no relationship whatever to this kind of Lutheranism. However, a general knowledge about Protestant Christianity makes it possible for me to try to close-read and interpret what the interviewees told me.

\section{ASTRID - THE RELUCTANT ACCEPTER}

Astrid and I conducted the interview in her combined kitchen-dining-and-livingroom (IF 2014: 1). It turned out that Astrid's coping mechanism consisted partly of a denial, partly of an attempt to accept the situation. She constructed her method of denial around her personal authority. Her self-assurance was one of her resources. Although Laestadians are faithful to the Bible, to my surprise Astrid said that one must be able to read between the lines in it. This utterance shows that she is a lady with much self-confidence also in religious matters. She told me that she had trusted and highly respected the preacher. For many years, she had attended his sermons and she had never seen that there was anything wrong with them. Although they were very severe, she had liked them for they reminded her of her youth in another congregation with the same kind of stern 
message. She had also discussed his sermons with her relatives and with her husband. Everyone had the same opinion. The sermons had been infallible.

When, in 2009, Astrid learned about the situation, her immediate reaction was disbelief although it was her own son who informed her. She was also very careful about with whom she spoke about it. This kind of scepticism, nearly denial, was her strategy of coping until she had to realise the facts. After 'everybody' knew about the scandal she received plenty of consolation from people around her outside of the community, which she took in a very positive manner. Her social relationships supported her. Her life experience and her relatives were a resource to her when she tried to appraise what had happened. This experience was certainly a resource that hindered her from condemning him once and for all. Therefore, in the interview, she often repeated her doubts about his character.

She asked her children if they had stopped believing in God after the disclosure, and she got a negative answer. It helped her to see a positive outcome of the scandal for indeed there had been quite an intense discussion and debates about paedophilia in the association of peace. As a consequence, many circumstances that had been difficult and too severe had been loosened. A new kind of activity spread and passive members returned. She felt happy for that. This was her reason to let me interview her for she thought it might be of some help to somebody in a corresponding situation if they learnt how this association of peace had handled paedophilia. To her an optimistic vision of the future was valuable.

Astrid had had a good relationship with the preacher's wife. She was disappointed on behalf of the wife who, as she said, had "seen many bad things". I interpret this utterance to the effect that Astrid related herself to the wife in order to explain to me why the wife had been such a good listener: a person who has wide life experience recognises other people's problems. Astrid referred to her personal authority when she judged the wife's situation. She also referred to her personal relationship in yet another way. She was active as a politician, which in this association of peace was nearly inconceivable. Women were not supposed to take a noticeable role outside the home, and above all, women were not allowed to preach. However, the preacher's family had supported her, which she underlined in the interview. I interpret her frustration partly also as a personal defeat when she saw that she had been promoted by a person who should not have earned her respect. Her life experience and authority had not been enough to reveal the preacher's character. She had no means to handle her feeling of being cheated.

It emerged in the interview that some of her children had thought that their Sunday school teacher was too fond of small children, which, however, did not make their mother react. Her respect for him had been too great. Now 
the scandal led some of them away from the association of peace, into other Christian groups, which she certainly found depressing. These children became central in her prayers.

When Astrid tried to understand what had happened, she admitted that there was no "pure" association of peace. Every human being, she said, had their own personal weaknesses and temptations. This was a clearly religious stance. She also referred to religion when she excused herself saying that as long as her children were small she was responsible for them, but now when they were adults they had to take care of themselves, for 'I cannot be responsible for my children and their house', she said. The use of 'house' is Biblical (see, for instance, Luc. 2: 4), and I interpreted it as if she wanted to shift the responsibility onto God.

Astrid could not understand why this highly respected preacher had become a paedophile. She appealed to religion for an answer, saying resignedly that one could not see it clearly (cf. 1 Cor. 13: 12), but realistically she also stated that one did not even want to know everything. Perhaps he had just become a dirty old man. Or, perhaps, his wife had been cold and unwilling to serve him in bed. Astrid referred to herself saying that she did not know the wife in this way, and then she mentioned that she could only pray that her dearest would never sin in that way. Her Christian education led her to the concept of sin and her life experience told her that one could never know what might happen. Finally I asked Astrid if she could see God's will in the situation. Her answer was undoubtedly positive. Prayers and belief in God were other resources for Astrid to come to grips with her situation.

Astrid presented yet another explanation for the preacher's character when she said that he had perhaps been a homosexual, implying that he had not been able to realise his sexual wishes due to his social status. This explanation I interpret as an idea from the ongoing debate on the postmodern acceptance of homosexuality. The contemporary cultural context influenced Astrid. However, she also excused herself with her inability to understand something of which she had no experience, just in the same way as she could not understand paedophilia. Here she ended in resignation.

Astrid was a doubter and denier. Firstly, her respect for the preacher and his position in the association of peace, almost as an earthly equivalent to God, the heavenly father, restrained her from easily accepting the rumour about him. She partly coped through the conservation of her opinion about the preacher (cf. Pargament 1997: 109). Consequently, her coping process was somewhat groping. However, she referred to her personal authority as a person with much experience from a long life. She saw herself as a very special kind of woman being something as rare as a Laestadian female politician. These perspectives 
gave her significance. I see her as a very self-confident person and definitely not as somebody to be easily cheated. Anyhow, my analysis indicates that she had been duped. Her worldview cracked. Therefore she mentioned her belief in God. Her orienting system led her to religion. Paedophilia was beyond her limits, and she was not able to tolerate such behaviour. Religion gave her the greatest significance in her belief in God and in a better life after this one, in peace with him, and in good conscience. She said that her Christianity was the most important. Perhaps this is the explanation for why she did not feel bitter after all. But anyway, all through the interview she negotiated with herself about how improbable the preacher's behaviour had been. Frustration with the preacher was still there, although she could see some positive perspectives in the situation. Her coping process was not yet completed.

\section{PER - THE DISAPPOINTED ACCEPTER}

Per and I met in the meetinghouse of the Laestadian association in Jakobstad. We sat on the very first bench just beneath the pulpit. The interview (IF 2014: 2) started abruptly when Per said that he remembered the revelation of the scandal as if a bomb had detonated. In fact he mentioned three different scandals. He had been able to discern other cases of sexual abuse or undesired sexual behaviour thanks to his experience from them. He stuck to this drastic language all through the interview. When he learned about the paedophile, everything "turned into zero". It was "chaos". He had even lacked words to show his Laestadian belonging, for he thought his association of peace had turned into a sect, which to him was almost a curse. He felt deceived and had been through a process of grieving, he said. I had the feeling that Per's anger came from his feeling of being hurt in his most central values. Per used expressions with association to bodily experience. It "cut him to the heart", "his legs had been cut off" when he realised what had happened. Abuse, he stated, damaged a person. Per classified the paedophile as a man of power who, like others of the kind, mostly "hid some shit" under a veil of being good. His language demonstrated to me that I had a temperamental person at my side. At the moment of interviewing, Per chose drastic words to communicate to me what he felt. His language was a means that gave vent to his feelings.

All through the interview Per demonstrated a reflexive way of regarding what had happened and his coping with it. He anchored the interview in his childhood, when he had sat on the same bench listening to his Sunday school teacher and taking everything he said for granted. As a child he had trusted his teacher. Such a strong preacher was almost a god, Per stated. Then he said that 
the disappointment that arose from the scandal was partly due to the broken trust for the preacher, but partly also due to his own inability to stand up for his faith. He had renounced his faith and was utterly ashamed. He had to cope with both the fact of paedophilia and his own cowardice.

To Per it was completely incomprehensible why a man would like to offend children. He could not imagine why a pious, respected preacher played this kind of double game, hiding so much dirt. He was very much aware that the preacher had done something against the law. In that way he referred to the cultural context and society around him. He could not understand why it took such a long time to reveal the scandal, but, according to Per, God wanted something with the preacher; he gave him the gift of preaching in order to strengthen the members of the congregation to get on with their lives despite what had happened.

Per expressed his disapproval of the preacher-Sunday school teacher's adherents in the association of peace for he thought it was too severe. He blamed them for having promoted too strict demands concerning life. It was impossible to fill all their requests. The demands were just touching the surface. Per stated that the preacher wanted a good Laestadian to have a special, yet superficial behaviour. He even maintained that it was no real belief. In this way he announced that he might know what real belief was. Per felt cheated. He was strong enough to condemn the preacher's view of Laestadianism and distanced himself from it.

Still, Per pondered the question why he had stayed in the Laestadian movement though things like this could happen, and explained to me that the feeling of security was too important to him to be ignored. He even negotiated with himself whether he should openly admit that he was a Laestadian. Would it not simply be enough to call oneself Christian, he asked. In this way he tried to find a means to keep some part of his faith. He was aware of the fact that everyone will die, and that death would not be frightening for he believed that God would offer him a better world on 'the other side'. To him death was a motivation for believing. His decision to stay in the association of peace was the result of a really well-thought-out choice. He had even pondered over alternatives but found that he did not like the Moslem religion; neither could he accept Jehova's witnesses. Consequently, he told me that he had stayed with the Laestadians for a couple of decades, and that tradition and his belief in God had bound him there. In this way Per created a religion in which he could feel intimate with God. Religion had nearly become an obstacle, but after reflection he stuck to his association of peace. It became clear that Laestadianism per se gave Per significance.

When Per mentioned difficulties, faults, and mistakes, he also tried to find an excuse and resources to manage. This was typical for him. For instance, he 
was aware of the catastrophe in connection with the paedophile, but he said it was good that the paedophile had been unmasked. He was ashamed of being a Laestadian, and stated that it might be better to call himself a Christian. The crisis that he went through when he realised how superficial faith could be led him to a deep personal faith, which he mentioned several times. He saw the scandal as a means from God to create a better future. A good conscience and a strong belief were guarantees for safety. His responsibility for his children led him to come to grips with the problems. Here God and his own children were resources for coping.

One of the most central components within Laestadianism is forgiveness. It is impossible to live the way God would like people to live, Per mentioned. Every person is a sinner and as sinners people do not feel good, they do not have any peace. Consequently, they should tell a trusted person about their sins, failings, and feelings, and ask for forgiveness. According to the Bible, Per said, this reliable person, be it a person's spouse, children or anybody else has the power to free a person from his or her sins. After that, Per mentioned, it is easy to live, for all mistakes are forgotten. To Per, forgiveness is nothing that strengthens faith, but it helps to believe. Belief in peace and forgiveness as the way to peace were important resources for Per. However, he was not naïve, for he counted with the possibility that people asked for forgiveness, received it, but continued sinning in the same manner anyway.

Per told me that the members of the association of peace had tried to rebuild it. Some members of his age had gathered to talk about the scandal. They had thrashed it out and resorted to humour and laughing in order to handle their memories.

To Per the Bible was the only authority. He referred to several Biblical quotations. He knew very well that man is a sinner. To Per the worst sin was disbelief. His deep knowledge of Laestadian theology, and his personal belief freed from his parents' wishes and from superficiality were among the factors that gave him significance. The very kernel in his report was his desperately repeated distrust of people. He stated his scepticism towards people at least a dozen times. His disappointment over people was radical. He had to rethink his way of living. I interpret his reluctance as a protection against further deeply disappointing experience of deceit by human beings. He could not tolerate anything of what had happened. However, typically enough he tried to find a positive way out of his distrust, for he did not limit his disappointment to people but also said that God was the only one to trust.

Per's significance was created out of his theological knowledge. To him his dissociation from Laestadianism, which resulted in his personal heartfelt and unsophisticated belief, was extremely important. But I also interpreted his report to the effect that his disappointment with human beings gave him 
significance. It was important to him to demonstrate his ability to discern what was really precious, in contrast to any kind of rubbish. From my point of view, Per had a special resource because of his ability to always formulate a problem or a negative viewpoint difficult to be accepted, and immediately tried to find means to solve the problem or complete the viewpoint, often with a positive alternative.

\section{TOM - THE EXPLAINING ACCEPTER}

Tom and I met for the interview in a café (IF 2014: 3). Although there were other people along with him, their conversation did not really disturb Tom in his account. He was very concentrated, and also very eloquent.

To Tom the revelation of paedophilia was not a surprise, for he had heard something about it before in a conversation with some relatives who were involved. He told me what had happened mainly by trying to search for and explain the causes. Perhaps he thought that if he could reveal the cause he would also have some kind of remedy. For a long time he did not say much about his personal viewpoints on the situation, but tried to find out what had made it possible for the paedophile to act. In his religious biography, Tom just mentioned that he vaguely remembered the preacher, and that he had been an appreciated person who was seen as an authority in biblical matters. However, Tom also often returned to concepts such as violence, grievous bodily harm, even torture as found in a family model in which the father had dominance and desired control over his social environment. This desire, said Tom, led to an exercise of power over his family members, which resulted in under-stimulation. Tom repeated this concept so often that it must be regarded as a central tool of thought for him. With under-stimulation Tom aimed at telling me about how severe the preacher had been towards his family members, how great demands he had made on them. Similar to Per, Tom referred to a façade, or even a wall, when he spoke about the religion of the preacher's family. He said that traditions had become religion, meaning that there was no real faith in their way of behaving. This, he meant, was treachery. According to Tom, the children in the preacher's family had been isolated; they had to work for their father, they did not get any education, they were not members of any sports club or other associations for young people, and the boys were hardly sent to military service - all in order to isolate them from worldly impressions, and from revealing what was happening in this highly dysfunctional family. Tom meant that the father's inclination was hidden behind this isolation. Moreover, 
he had been thinking that the inclination was an expression of homosexuality impossible to be acted out in the association of peace.

According to Tom the preacher had asked for forgiveness and he had also received it. Tom explained how forgiveness worked as a disguise for truth. If somebody asked for forgiveness, a friend, family member or some trusted person could give it and after that it was not possible to take that very issue to discussion again. The one who did so almost had a death sentence hanging over their neck. They almost committed a mortal sin. Consequently, it was impossible to control the life of the preacher from outside, said Tom.

Tom also mentioned that isolation let the children stay children although they were big enough to reach puberty and emancipation. For two years he saw these victims on a regular basis and listened to them and their stories. The men lacked a will of their own, and consequently, according to Tom, they were easily persuaded to do and to accept things that they really should not have. They were also afraid of advice and defiant, just like teenagers, for they had not had the opportunity to liberate themselves at the right age. Only adult men's strong wives had made them able to draw a line between what was acceptable or demanded from a man, and what was not.

Almost half of the interview consisted of Tom's account of what had happened and his explanations for why it had happened. Until then he had not said anything about his personal reactions. I even asked him about his feelings when he learned what had happened. He said that perhaps he would not have believed what he had heard, had his partner in the conversation not portioned his information into small pieces. For a long time he disclosed more and more information to Tom and slowly it grew to form a whole that Tom believed. He was rather relieved, for he said he had "found a big piece in a soup", which explained to him why awkward things had been so awkward.

When he regarded homosexuality as the grounds for paedophilia, Tom clearly stated that this was his personal opinion. Here he referred to the same debate about homophobia in society as Astrid. The core of his personal way of coping was his satisfaction with being able to help the victims. He was grateful for being able to listen to them, to try to make them look at themselves from an adult's perspective. His significance lay in the fact that his close contact with those who had been mistreated made him know considerably more about the whole process than people did in general. He said that he had been aflame with eagerness to understand and help the victims and wanted to tell about the situation, for he believed in openness. This goes well with his main explanation for the entire situation as a result of being shut in and living in isolation. He said that he wanted to speak to the victims for he wanted to learn something from their experiences. He wanted to know how people reacted in such severe 
situations. Tom took advantage of the situation in order to develop himself. Similar to the other interviewees, his orienting system was so strongly connected to Laestadianism that he stuck to the community and wanted to help improve it, although some other members thought that he was too energetic and wanted to change too much and too fast. Finally he, like Per, also stated that he had had great fun with the men when they talked about their experiences.

While I listened, he was trying to understand what had happened and verbalised the likely process. He put quite an effort into identifying the problem. For instance, he referred to the very situation when the paedophile had been active, and how people around him had coped with the situation when they excused him by saying that he had only touched the child's trousers. He also told me how he personally had reacted. He mentioned that he had wanted to involve himself in the issue in order to see what had gone wrong. Still, he had not wanted to be too active in order not to damage the victims even more. He had activated himself as a means of being part of the process. Later it turned out that he had regarded himself as a tool, a resource, in the process of helping the victims.

Tom was a free-spoken talker. He did not mince matters in our conversation. To me it became clear that Tom's resource was our conversation. When he made a complete account of the process with all its ingredients he also was the master of the situation. He painted images in his talk, and, consequently, his association with drama and the idea of creating a documentary around the Jakobstad association of peace was not far-fetched. A characteristic of his conversation was his custom to psychologize. I do not know how much literature of the kind he had read, but he searched for psychological explanations to all phases and perspectives of what had happened. I interpreted his talk as a semi-scientific analysis of the results that he had reached during two years of regular conversations with people in distress. Strictly spoken, Tom was not disappointed, but rather proud of his role. His choice was to play the role of a consoler and helper. He transformed his role in the relationship to the victims and became their therapist. Religion was not central in his conversation with me, but his orientation system was founded in the Pauline message to carry each other's burdens (Gal. 6: 2). Life was a mission for him.

\section{CONCLUDING REMARKS}

At the beginning of this article I stated that in the coping process religion might play the role of an obstacle for further belief, but it might also serve as a support for the congregation members. What was the case in the Laestadian association of peace in which paedophilia emerged? 
In order to be able to cope, there must be a norm or a set of norms that tell us what is right and what is wrong. These norms are religiously, culturally, and/or socially grounded. It turned out that the interviewees coped in quite different ways. Everyone had their own way, and everyone created their personal significance. Astrid was still not ready to accept facts completely. Based on the resources available to her, she was bent on preservation (cf. Pargament 1997: 111). Per had created a personal variant of Laestadianism, which made it possible for him to re-valuate his position (ibid.). Tom reconstructed his role of a passive observer and coped through his actions as a helper (ibid.). Certainly, everyone was aware that paedophilia was not an accepted behaviour for an adult, but it was not unswerving how to cope with it. The religious background within Laestadianism gave the preacher a high status, even as an earthly equivalent to God in heaven. Subsequently, the revealed truth made his fall so much deeper and the frustration felt by the members of the community correspondingly severer, which they expressed in doubt. Their orientation system as Laestadian Christians would not allow for such a failure. They chose to extend their toleration and try to find excuses. Here religion supported them - against general opinions about paedophilia. They had enough resources to perceive something positive in the critical situation.

Religion was a resource that helped them to see clearly. Paedophilia is a punishable offence against Finnish laws. It is also a sin. Consequently, according to Laestadian norms, it should be confessed and forgiven. This had happened but obviously, according to my material, the sinner had continued to sin anyway. However, in coping with the scandal, the interviewees did not doubt the function and meaning of forgiveness. On the contrary, forgiving was still underlined as a very important and relieving phenomenon within Laestadianism. The problem of sin on grace was not really relevant in the interviews.

The interviewees referred to the resource of their former experiences when they mentioned their memory of former cases of a sexual kind. Their memory helped the interviewees to recognise paedophilia as an incorrect action and to see the difference between secure and insecure situations and ponder correcting activities. Their ability to verbalise their thoughts helped the interviewees to handle the situation. Their skill to organise facts, according to their view, into a logically consistent account gave them a feeling of mastering the situation. This feeling, however, had not come without contrition, the outcome of which was partly understanding, and partly rejecting. These components were rooted in religion. Understanding meant love and forgiveness, rejecting meant repudiation of sin. Understanding also indicated an awareness of man's weaknesses, whereas the consequence of rejecting denoted an effort to find a way out by finding another religious affiliation or by helping the victims. All these abilities were cultural, social, and religious resources. Not until this consistent 
whole had been formulated could the interviewees feel relief from tension. Afterwards, they could act and react in a significant way.

To begin with, when the preacher turned out to be a paedophile, one could imagine that the worldview of the interviewees was damaged. Order became chaos, security turned into insecurity. This was the case when the interviewees stated that they could not believe what had happened. Respect for the preacher could have turned into contempt towards the paedophile. However, religion helped the interviewees to cope with the situation. Life experience let them see that people are different and not thoroughly immaculate. Religion gave them remedies: one could try to re-shape the work in the association of peace, one could also regard the situation as due to chance, when helping the victims, to get to know human beings' reactions in order to derive advantage from this knowledge in other corresponding situations. One could even try to find a way out by renaming one's religious affiliation from Laestadian to Christian. The image of the hero, the preacher, had changed, which called for a new hero, God himself.

Significance was religiously founded in the interviews. Christianity in its Laestadian version was the most important thing to Astrid. It was extremely important to Per, but only after he had analysed the pros and cons in its Laestadian form. It was also important to Tom, who had remained active within the association of peace although he had met with criticism. Each of the interviewees created significance in different ways, but each of them also wove religion into it. I would even like to interpret the interviews as a way to handle the chaotic situation. The interviews were an opportunity to sort out things in a belief in a better world to come. In other words, the old narrative had broken down, but a new narrative was created: the preacher was a sinner, but a reformed personal and congregational work would be the prerequisite for a continuation of God's realm on earth. Through all the interviews, it became clear that the orientation system of Laestadianism was stronger than anything else. In an overarching perspective, religion was a supporting resource in their coping processes.

\section{NOTES}

1 This article was written under the project called Toleransens gränser (The Limits of Tolerance) financed by the Academy of Finland. For historical reasons, in Finland some place names are both in Finnish and Swedish. The Finnish variants are generally the official names used in foreign languages. Consequently, the community that I refer to is called Pietarsaari. However, the main language within the association is Swedish. Therefore, I prefer to use Jakobstad, which is the Swedish name.

2 Email from Gerd Snellman, 3 April 2014. 
3 Paedophilia is a returning and recent problem in many institutions, churches, or associations where men and boys meet. Only in 2013-2014 there were writings about repeated instances in another Laestadian association of peace in northern Finland (Huuskonen \& Katajamäki 2014; see also Hurtig \& Leppänen 2012, a collection of essays about paedophilia). A Methodist community saw a parallel case. For decades, the Catholic Church had been struggling with paedophilia in different countries. There were problems in children's day care homes. The same goes for sports associations.

4 Research on Laestadianism is comprehensive. For more information, see, for instance, Talonen 1993, 2014, 2016; Raittila 1976,1969; Suolinna \& Sinikara 1986; Palola 2014; Vuollo 1999; Nurminen 2016.

5 Cf. Kaaro (2016), who deals with the problem of false memories of paedophilia among Laestadians. Perhaps stories about paedophilia might be a kind of folklore within the movement (cf. Campion-Vincent 2015).

\section{MANUSCRIPT SOURCES}

Cultura, the Abo Akademi University Archive of folk life and traditions: cultural archive IF mgt 2014: 001, IF mgt 2014: 002, IF mgt 2014: 003.

Snellman, Gerd 2014. Email to Ulrika Wolf-Knuts, 3 April.

\section{REFERENCES}

Brännström, Olaus 1962. Den laestadianska själavårdstraditionen i Sverige under 1800-talet. [The Laestadian Tradition of Curing in the 19th-Century Sweden.] Uppsala: C.W.K. Gleerups förlag.

Campion-Vincent, Véronique 2015. Children as Prey: A Case of the Utmost Contemporary Legends of Organ Theft, Children's Disappearances, Kidnappings, and the Sexual Abuse of Children and Adolescents. Folklore: Electronic Journal of Folklore, Vol. 62, pp. 81-110. http://dx.doi.org/10.7592/FEJF2015.62.campion-vincent.

Hurtig, Johanna \& Leppänen, Mari (eds.) 2012. Maijan tarina: Lapsen seksuaalinen hyväksikäyttö yhteisön ja yksilön traumana. [Maija's Story: Child Abuse as a Trauma of the Community and Individual.] Helsinki: Kirjapaja.

Huuskonen, Matti \& Katajamäki, Aimo 2014. Lestadiolaisjohtaja antoi hyväksikäyttäjän välttää poliisin. [Leader of the Laestadian Movement Helped the Abuser Avoid the Police.] Helsingin Sanomat, 5 January. Available at https://www.hs.fi/sunnuntai/ art-2000002700405.html, last accessed on 3 July 2020.

Kaaro, Jani 2016. Lestadiolaiset modernilla noitaroviolla. [Laestadians at a Modern Witch Bonfire.] Rapport, 2 November. Available at https://www.rapport.fi/journalistit/ jani-kaaro/lestadiolaiset-modernilla-noitaroviolla, last accessed on 3 July 2020.

Lampa, Rolf 2009. Pedofilskandal i Jakobstad i finländska Österbotten. [A Paedophile Scandal in Pietarsaari, Finnish Ostrobothnia.] RIL News, 19.3.2014. Available at http://rilnews.org/article/pedofilskandal-i-jakobstad-i-finlandska-osterbotten, last accessed on 3 July 2020. 
Nurminen, Hanna 2016. Jumala vai minä? Kaksi käsitystä vanhurskauttamisesta 1970-luvun vanhoillislestadiolaisuudessa. [God or Me? Two Different Understandings of Justification within Conservative Laestadianism in the 1970s.] Diss. (PhD Thesis). University of Helsinki. Available at http://hdl.handle.net/10138/166230, last accessed on 3 July 2020.

Palola, Tuomas 2014. Amerikkalainen vai pohjoismainen? Amerikan apostolicluterilaisuus 1884-1929. [American or Scandinavian: American Apostolic Lutheranism 1884-1929.] Oulu: Suomen Rauhanyhdistysten Keskusyhdistys.

Pargament, Kenneth I. 1997. The Psychology of Religion and Coping: Theory, Research, Practice. New York \& London: The Guilford Press.

Raittila, Pekka 1969. Väckelse och kyrka under senare hälften av 1800-talet. [Revival and Church during the Second Half of the 19th Century.] In: Anders Pontoppidan Thyssen (ed.) Väckelse och kyrka i nordiskt perspektiv: Nordiska studier över brytningarna mellan kyrklig ordning och religiös folkrörelse under 1800-talet. [Revival and Church in a Nordic Perspective: Nordic Studies of the Rifts between Church Order and Religious Popular Movement during the 19th Century.] Skrifter utgivna av Nordiskt Institut för kyrkohistorisk forskning 1. Copenhagen: Gad, pp. 99-114.

Raittila, Pekka 1976. Lestadiolaisuus 1860-luvulla: Leviäminen ja yhteisönmuodostus. [Laestadianism in the 1860s: Distribution and Formation of a Community.] Helsinki: Akateeminen kustannusliike.

Snellman, Gerd 2011. Sions döttrar: De laestadianska kvinnorna som traditionsförmedlare i norra svenska Österbotten åren 1927-2009. [Daughters of Sion: The Laestadian Women as Transmitters of Tradition in Northern Swedish Ostrobothnia 19272009.] Åbo: Åbo Akademis förlag.

Suolinna, Kirsti \& Sinikara, Kaisa 1986. Juhonkylä: Tutkimus pohjoissuomalasesta lestadiolaiskylästä. [Juhonkylä: A Study of a Laestadian Village in Northern Finland.] Helsinki: Suomalaisen Kirjallisuuden Seura.

Talonen, Jouko 1993. Esikoislestadiolaisuus ja suomalainen yhteiskunta 1900-1944. [Firstborn Laestadians and the Finnish Society 1900-1944.] Suomen kirkkohistoriallisen seuran toimituksia 163. Helsinki: Suomen kirkkohistoriallinen seura.

Talonen, Jouko 2014. Lestadiolaisuuden synty, leviäminen ja hajaannukset. [The Emergence, Distribution, and Dispersion of Laestadianism.] Teologinen Aikakauskirja / Teologisk tidskrift, Vol. 119, pp. 19-34.

Talonen, Jouko 2016. Lestadiolaisuus muuttuvan ajan paineissa. [Laestadianism under the Pressure of Changes of Time.] Perusta, Vol. 3, pp. 133-147. Available at https://www.perustalehti.fi/2016/05/lestadiolaisuus-muuttuvan-ajan-paineissa/, last accessed on 3 July 2020.

Vuollo, Martti 1999. Lestadiolaisuus Helsingissä vuoteen 1963. [Laestadianism in Helsinki until 1963.] Studia Historica Septentrionalia 37. Rovaniemi: PohjoisSuomen historiallinen yhdistys.

Ulrika Wolf-Knuts is Emeritus Professor of folkloristics at Åbo Akademi University, Åbo (Turku), Finland. Her special fields of interest are folk belief, folk religion, identity, and Finland-Swedish folklore.

uwolf@abo.fi 